\title{
PENGARUH DIRECT LABOR COST DAN BIAYA MAINTANANCE MESIN PRODUKSI INJECTION TERHADAP VOLUME PRODUKSI KURSI PLASTIK NAPPOLY (BIG 909) STUDI KASUS DI PT. CAHAYA BUANA INTITAMA BOGOR
}

\author{
M.Rizal Satria, Kemal Syaiful Anwar \\ Politeknik Pos Indonesia, \\ rizalstr@gmail.com, kemalanwar32@gmail.com
}

\begin{abstract}
ABSTRAK
Penelitian ini mempunyai tujuan untuk mengetahui dan menganalisis pengaruh Direct Labor Cost Dan Biaya Maintanance Mesin Produksi Injection Terhadap Volume Produksi Kursi Plastik Nappoly (Big 909) Study Kasus Di PT. Cahaya Buana Intitama Bogor. yang man jenis penelitian yang digunakan menggunakan kuantitatif metode dengan populasi yaitu seluruh data laporan keuangan yang terdapat pada perusahaan PT. Cahaya Buana Intitama. Adapun alat analisis yang digunakan yaitu uji normalitas, uji analisis korelasi person product momen, analisis korelasi berganda, regresi linier berganda, koefisien determinasi, uji t (parsial), dan uji f (stimultan). Didalam analisis menggunakan IBM Statistics Versi 25.0 dapat disimpulkan hipotesis pertama terdapat pengaruh secara negatif direct labor cost terhadap volume produksi, hipotesis kedua terdapat pengaruh positif biaya maintanance mesin produksi injection terhadap volume produksi kemudian hipotesis ketiga berpengaruh secara simultan antara direct labor cost dan biaya maintanance mesin produksi injection terhadap volume produksi.
\end{abstract}

\section{Kata Kunci : Direct Labor Cost, Biaya Maintanance, dan Volume Produksi}

\begin{abstract}
This study aims to determine and analyze the effect of Direct Labor Cost and Maintenance Cost of Injection Production Machines on the Production Volume of Nappoly Plastic Chairs (Big 909) Case Study at PT. Cahaya Buana Intitama Bogor. Which type of research used is a quantitative method with a population that is all financial statement data contained in the company PT. Intitama Buana Light. The analytical tools used are normality test, person product moment correlation analysis test, multiple correlation analysis, multiple linear regression, coefficient of determination, $t$ test (partial), and f test (simultaneous). In the analysis using IBM Statistics Version 25.0, it can be concluded that the first hypothesis has a negative effect on direct labor costs on production volume, the second hypothesis there is a positive effect on the maintenance costs of injection production machines on production volume, then the third hypothesis has a simultaneous effect between direct labor costs and production machine maintenance costs. injection against production volume.
\end{abstract}

Keywords: Direct Labor Cost, Maintenance Cost, and Production Volume 


\section{PENDAHULUAN}

Pertumbuhan bisnis di Indonesia semakin cepat dan pesat. Dimana industri manufaktur Indonesia terus meningkatkan produktivitas dan perkembangan usaha yang digunakan untuk mencapai tujuan dalam memenuhi kebutuhan pasar domestik dan ekspor. Didalam sektor industri perkembangan dan kemajuan ilmu pengetahuan maupun teknologi sudah menjadi tuntutan yang dihadapi, sehingga mengakibatkan tingginya dorongan dalam persaingan kearah kompetisi yang semakin ketat. Dimana perusahaan mempertimbangkan semua aspek yang mempengaruhi kestabilan internal perusahaan khususnya seperti biaya tenaga kerja langsung, biaya pemeliharaan hingga volume produksi yang dihasilkan perusahaan.

Didalam sektor industri perkembangan dan kemajuan ilmu pengetahuan maupun teknologi sudah menjadi tuntutan yang dihadapi, sehingga mengakibatkan tingginya dorongan dalam persaingan kearah kompetisi yang semakin ketat. Dimana perusahaan mempertimbangkan semua aspek yang mempengaruhi kestabilan internal perusahaan khususnya seperti biaya tenaga kerja langsung, biaya pemeliharaan hingga volume produksi yang dihasilkan perusahaan. Volume produksi itu sendiri masuk dalam salah satu pertimbangan dalam meningkatkan bisnis perusahaan, karena volume produksi itu dapat digunakan untuk mengetahui sejauh mana tingkat aktivitas perusahaan khususnya produksi untuk mengukur seberapa banyak unit produksi yang dihasilkan untuk tercapainya titik impas yang dibutuhkan perusahaan. Tenaga kerja merupakan suatu kebutuhan yang sejak awal memiliki peranan penting dalam menjalankan produksi bahkan hingga produksi tersebut dipasarkan.

Tenaga kerja yang baik yaitu yang mempunyai sifat pekerja keras, ulet, disiplin dan profesional. Menurut UU No 13 Tahun 2003 Bab 1 Pasal 1 ayat 2 menyatakan bahwa tenaga kerja adalah setiap orang yang mampu melakukan pekerjaan guna menghasilkan barang dan atau jasa baik untuk memenuhi kebutuhan sendiri atau untuk masyarakat. Dimana sumber daya khususnya pihak tenaga kerja dalam menjalankan tugas tidak hanya dikerjakan sendiri melainkan akan dibantu oleh tenaga mesin untuk memudahkannya, maka didalam mendukung kinerja alat tersebut dibutuhkan biaya pemeliharaan (maintenance) secara berkala agar mesin akan selalu optimal dalam produksi sehingga kebutuhan pasar dapat terpenuhi. Menurut (Tampubolon, 2018) biaya pemeliharaan (maintanance) dapat diartikan sebagai kegiatan memelihara fasilitas atau peralatan pabrik melakukan perbaikan, penyesuaian ataupun yang diperlukan agar supaya terdapat suatu keadaan operasi yang memuaskan sesuai dengan apa yang direncanakan.

Dimana didalam penentuan volume produksi barang harus diperhitungkan secara teliti, apabila terjadi kesalahan dan mengakibatkan tingginya intensitas volume produksi yang di buat maka akan menyebabkan tingginya stok penyimpanan didalam gudang dan apabila lebih rendah maka akan mengurangi peredaran produk dipasaran yang dapat menyebabkan tidak seimbangnya biaya yang dikeluarkan dengan pendapatan penjualan, sehingga dapat mengakibatkan kerugian bagi usaha industri tersebut. Masalah penentuan volume produksi tidak hanya dialami perusahaan sendiri melainkan seluruh perusahaan salah satunya perusahaan dibidang manufaktur PT. Cahaya Buana Intitama yang dapat dilihat dari fenomena, yang telah dikemukan oleh Bank Indonesia industri pengolahan pada kuartal IV 2019 tumbuh melambat yang dapat dilihat pada. Senin (13/01/2020, 16:02 WIB, https://money.kompas.com/read/2020/01/13/160200826/kinerja-industri-manufakturmelambat-di-akhir-2019-mengapa-).

Selain fenomena tersebut terdapat masalah terbaru yang menimpa seluruh perusahaan yaitu masalah episentrum COVID-19 yang sangat merugikan semua kalangan khususnya industri manufaktur. Yang mana data terakhir Badan Pusat Statistik (BPS), Februari 2020 
nilai impor a golongan barang menurun yang dapat dilihat pada . Rabu (01/04/2020, 08:30 WIB, https://katadata.co.id/telaah/2020/04/01/pukulan-dua-arah-virus-corona-ke-industrimanufaktur).

Sesuai dengan penelitian tentang yang dilakukan oleh (Hermawan, 2019) tentang "Pengaruh Jumlah Persediaan Bahan Baku dan Kapasitas Mesin Terhadap Volume Produksi Pada UD. Cahaya Restu Kota Probolinggo" menghasilkan kesimpulan bahwa kapasitas mesin memiliki pengaruh terhadap volume produksi dan dari (Tukasno, 2017) tentang "Pengaruh Biaya Bahan Baku dan Biaya Tenaga Kerja Terhadap Produksi Tungku Di Desa Braja Mulya Kecamatan Braja Selebah" yang di peroleh kesimpulan bahwa adanya pengaruh antara tenaga kerja terhadap volume produksi. Kemudian hasil oleh (Badriah, 2016) yaitu pengaruh biaya pemeliharaan dan perbaikan aktiva tetap terhadap volume produksi pada perusahaan daerah air minum Tirta Anom Kota Banjar yang memperoleh kesimpulan terdapat pengaruh signifikan antara biaya pemeliharaan terhadap volume produksi. Maka dilihat dari fenomena, data perusahaan dan hasil Untuk penelitian yang telah dijelaskan sebelumnya, penulis tertarik untuk melakukan penelitian dengan judul "Pengaruh Direct Labor Cost Dan Biaya Maintanance Mesin Produksi Injection Terhadap Volume Produksi Kursi Plastik Nappoly (Big 909) Study Kasus Di PT. Cahaya Buana Intitama Bogor".

Berdasarkan dengan latar belakang penelitian dalam laporan, agar penelitian terfokus pada bahasan yang telah ditentukan sebagai dasar acuan dan tidak meluas, penulis kemudian menentukan sebagai berikut:

1. Bagaimana pengaruh direct labor cost terhadap volume produksi kursi plastik nappoly (big 909) study kasus di PT. Cahaya Buana Intitama ?

2. Bagaimana pengaruh biaya maintanance mesin produksi injection terhadap volume produksi kursi plstik nappoly (big 909) studi kasus di PT.Cahaya Buana Intitama?

3. Bagaimana pengaruh direct labor cost dan biaya maintanance mesin produksi injection terhadap volume produksi kursi plastik nappoly (big 909) studi kasus di PT. Cahaya Buana Intitama.

\section{KAJIAN PUSTAKA}

\section{Biaya Tenaga Kerja Langsung (Direct Labor Cost)}

Menurut (Mulyadi, 2016) tenaga kerja adalah upaya fisik dan mental karyawan untuk memproses produk. Biaya tenaga kerja adalah harga yang dibebankan untuk penggunaan tenaga kerja manusia tersebut.

Menurut UU No 13 Tahun 2003 Bab 1 Pasal 1 ayat 2 menyatakan bahwa tenaga kerja adalah setiap orang yang mampu melakukan pekerjaan guna menghasilkan barang dan atau jasa baik untuk memenuhi kebutuhan sendiri atau untuk masyarakat. Dari beberapa pengertian tersebut dapat disimpulkan bahwa Biaya tenaga kerja langsung adalah bagian dari upah yang dapat secara khusus dan konsisten dialokasikan atau terkait dengan pembuatan produk pada lini produksi.

\section{Pemeliharaan (Maintanance)}

Menurut (Tampubolon, 2018) pemeliharaan (maintanance) dapar diartikan sebagai kegiatan untuk memelihara atau menjaga fasilitas atau peralatan pabrik dan mengadakan perbaikan atau penyesuaian maupun pergantian yang diperlukan agar terdapat suatu keadaan operasi produksi yang $m$ biaya service, biaya penyesuaian (adjustment) dan biaya perbaikan atau reparasi".

\section{Volume Produksi}


Menurut (Gitosudarmo, 2015) volume produksi merupakan suatu interaksi antara bahan dasar, bahan pembantu, tenaga kerja, dan mesin-mesin serta alat perlengkapannya yang dipergunakan. Menurut (Herjanto, 2015) volume produksi merupakan hasil dari proses produksi yang berhubungan dengan penciptaan barang dan jasa atau kombinasinya melalui proses transformasi dari masukan sumber daya produksi menjadi output yang diinginkan. Dari beberapa pengertian tersebut dapat disimpulkan bahwa volume produksi merupakan suatu barang yang dihasilkan melalui serangkaian kegiatan dalam proses produksi yang mana output atau keluaran hasil dari proses produksi yang dilakukan berupa barang atau jasa yang berguna bagi masyarakat sesuai dengan fungsi dan kegunaannya.

\section{METODE PENELITIAN Jenis Penelitian}

Jenis penelitian yang dilakukan menggunakan metode kuantitatif yang mana kuantitatif metode digunakan pada penelitian yang menggunakan angka dan menggunakan analisa assosiatif untuk mengetahui pengaruh direct labor cost terhadap volume produksi kursi plastik nappoly (big 909) study kasus di PT. Cahaya Buana Intitama, pengaruh biaya maintanance mesin produksi injection terhadap volume produksi kursi plstik nappoly (big 909) studi kasus di PT.Cahaya Buana Intitama dan pengaruh direct labor cost dan biaya maintanance mesin produksi injection terhadap volume produksi kursi plastik nappoly (big 909) studi kasus di PT. Cahaya Buana Intitama.

\section{Populasi}

Dalam penelitian ini populasi merupakan objek atau batasan area bagi peneliti yang secara luas atau keseluruan digunakan untuk keperluan penelitian. Maka sesuai dengan ungkapan tersebut, yang dimaksud objek dalam populasi bukan harus selalu orang, melainkan juga benda dengan kualitas dan karakteristik tertentu yang menunjukkan bagian atau dapat diproses, dianalisis, dan dinilai sebagai bahan penelitian dan kemudian dapat menghasilkan suatu hasil penelitian yang dapat ditarik menjadi sebuah kesimpulan. Sesuai dengan hal yang telah diungkapkan mengenai populasi penelitian, dalam penelitian ini peneliti secara umum menggunakan laporan keuangan PT. Cahaya Buana Intitama dan juga laporan volume produksi kursi plastik nappoly (big 909) PT. Cahaya Buana Intitama sebagai populasi penelitian.

\section{Sampel}

Peneliti secara umum menggunakan sampel non-probabbility sampling digunakan peneliti sebagai teknik pengambilan sampel dengan menggunakan pendekatan penentuan sampel secara purposive sampling, yang mana kriteria pengambilan sampel yang ditentukan peneliti dapat ditarik dari sampel yang diambil yaitu :

1. Untuk mecari data direct labor cost maka diambil dari laporan biaya upah langsung plastik.

2. Untuk mecari data biaya maintanance mesin produksi injection maka diambil dari laporan biaya maintanance mesin produksi injection.

3. Untuk mecari data volume produksi kursi plastik nappoly (big 909) maka diambil dari laporan biaya bahan baku, biaya tenaga kerja dan foh plastik kursi plastik nappoly (big 909).

Berdasarkan kriteria yang ditentukan peneliti, jika kriteria tersebut dapat dipenuhi digunakanlah sampel yaitu laporan biaya tenaga kerja langsung, biaya maintanance mesin produksi injection perbulan selama tahun 2016-2018 dan biaya produksi kursi plastik nappoly (big 909) perbulan selama tahun 2016-2018 pada PT. Cahaya Buana Intitama.

\section{Teknik Pengumpulan Data}

Didalam penelian ini jenis data berupa sukender data dengan mengunakan metode studi dokumentasi yang mana data penelitian yang digunakan bersifat time series dan cross 
section maupun menggunakan studi kepustakaan yang mana menurut Menurut (Sunyoto, 2016), studi kepustakaan (library research) adalah ...... teknik pengumpulan data dengan mempelajari buku-buku yang ada hubungannya dengan obyek penelitian atau sumbersumber lain yang mendukung penelitian". Sehingga penelitian dapat terlaksana sesuai dengan teori-teori dan kenyataan yang ada dilapangan.

Adapun alat analisis peneliti pakai yaitu uji normalitas, analisis korelasi pearson product, analisis korelasi berganda, analisis regresi linier berganda, analisis koefisen determinasi, uji statistik hipotesis t (parsial) dan uji statistik hipotesis $\mathrm{f}$ (simultan).

\section{HASIL PENELITIAN DAN PEMBAHASAN} Analisis Uji Normalitas

Dimana didalam analisis ini dengan menggunakan SPSS Versi 25 dengan One-Sample Kolmogorov-Smirnov Test sebagai berikut :

\section{Tabel 1}

Uji Normalitas Data

\begin{tabular}{|c|c|c|}
\hline \multicolumn{3}{|c|}{ One-Sample Kolmogorov-Smirnov Test } \\
\hline & & $\begin{array}{l}\text { Unstandardized } \\
\text { Residual }\end{array}$ \\
\hline \multicolumn{2}{|l|}{$\mathrm{N}$} & 36 \\
\hline \multirow[t]{3}{*}{ Normal Parameters ${ }^{2 b}$} & Mean & .0000001 \\
\hline & Std. & 208339447,865806 \\
\hline & Deviation & 55 \\
\hline \multirow{3}{*}{$\begin{array}{l}\text { Most Extreme } \\
\text { Differences }\end{array}$} & Absolute & .143 \\
\hline & Positive & .143 \\
\hline & Negative & -.080 \\
\hline \multicolumn{2}{|l|}{ Test Statistic } & .143 \\
\hline \multicolumn{2}{|l|}{ Asymp. Sig. (2-tailed) } & $.060^{\mathrm{e}}$ \\
\hline \multicolumn{3}{|c|}{ ๑. Test distribution is Normal. } \\
\hline \multicolumn{3}{|l|}{ b. Calculated from data. } \\
\hline \multicolumn{3}{|c|}{ c. Lilliefors Significance Correction. } \\
\hline
\end{tabular}

Berdasarkan hasil analisis uji normalitas yang dilihat pada tabel 1.1 dan mengacu pada kolom Kolmogorov-Smirnova menunjukan bahwa Variabel Y Volume Produksi Kursi Plastik Nappoly (Big 909), Variabel X1 Direct Labor Cost, Variabel X2 Biaya Maintanance Mesin Produksi Injection memiliki nilai Sig. sebesar 0,060. Dimana angka tersebut menunjukan $0,060 \geq 0,05$ maka dari hasil data tersebut dapat disimpulkan berdistribusi normal.

\section{Analisis Regresi Linier Berganda} berikut

Dimana didalam regresi linier berganda. Berikut adalah hasil pengolahan sebagai

Tabel 2

Analisis Regresi Linier Berganda

\begin{tabular}{|c|c|c|c|c|c|c|}
\hline \multicolumn{7}{|c|}{ Coefficients $^{\mathrm{a}}$} \\
\hline & \multirow[t]{2}{*}{ Model } & \multicolumn{2}{|c|}{ Unstandardized Coefficients } & \multirow{2}{*}{$\begin{array}{c}\begin{array}{c}\text { Standardize } \\
d \\
\text { Coefficients }\end{array} \\
\text { Beta }\end{array}$} & \multirow[t]{2}{*}{$t$} & \multirow[t]{2}{*}{ Sig. } \\
\hline & & B & Std. Error & & & \\
\hline \multirow[t]{3}{*}{1} & (Constant) & $\begin{array}{r}457899149, \\
871 \\
\end{array}$ & $\begin{array}{r}335248517, \\
382 \\
\end{array}$ & & 1,366 & , 181 \\
\hline & Direct Labor Cost & $-4,847$ & 2,123 &,- 571 & $-2,283$ & ,029 \\
\hline & $\begin{array}{l}\text { Biaya } \\
\text { Maintanance }\end{array}$ & 54,526 & 13,036 & 1,047 & 4,183 &, 000 \\
\hline
\end{tabular}


Berdasarkan hasil analisis regresi linier berganda yang dilihat pada tabel 1.2 , maka didapatkan persamaan sebagai berikut:

$\mathrm{Y}=\mathrm{a}+\mathrm{b} 1 \mathrm{X} 1+\mathrm{bX} 2$

$\mathrm{Y}=457.899 .149,871-4,847 \mathrm{X} 1+54,526 \mathrm{X} 2$

Persamaan tersebut dapat diartikan

1. Konstanta

Jika variabel direct labor cost (X1) dan biaya maintanance mesin produksi injection (X2) nilainya 0 , maka nilai variabel volume produksi (Y) adalah sebesar 457.899.149,871.

2. Direct labor cost (X1) terhadap volume produksi (Y)

Koefisien regresi variabel direct labor cost (X1) sebesar $-4,847$ artinya jika variabel direct labor cost (X1) mengalami kenaikan satu, maka volume produksi (Y) akan mengalami kenaikan sebesar 4,847. Karena koefisien bernilai negatif terjadilah hubungan negatif pula antara direct labor cost (X1) terhadap volume produksi (Y). Jadi, kenaikan direct labor cost (X1) mengakibatkan penurunan pada volume produksi (Y).

3. Biaya Maintanance Mesin Produksi Injection (X2) terhadap Volume Produksi (Y)

Koefisien regresi variabel biaya maintanance mesin produksi injection (X2) sebesar 54,526 artinya jika variabel Maintanance mesin produksi injection (X2) terjadinya kenaikan satu, volume produksi (Y) mengalami peningkatan sebesar 54,526. Karena koefisien bernilai positif maka terjadi hubungan positif pula antara biaya maintanance mesin produksi injection (X2) terhadap volume produksi (Y). Jadi, kenaikan biaya maintanance mesin produksi injection (X2) mengakibatkan peningkatan pada volume produksi $(\mathrm{Y})$.

\section{Analisis Koefisien Determinasi}

Dimana didalam analisis koefisien determinasi digunakan melihat pengaruh persentase antara variabel. Berikut adalah pengolahan hasil sebagai berikut:

Tabel 3

Analisis Koefisien Determinasi

\begin{tabular}{|c|c|c|c|c|c|c|}
\hline & \multicolumn{5}{|c|}{ Model Summary } & \multirow{4}{*}{$\begin{array}{l}\text { pada tabel } 1.3 \\
0,411 \text {. Berikut }\end{array}$} \\
\hline \multirow{3}{*}{$\begin{array}{l}\text { Berdasarkan } \\
\text { diatas, menunjuki } \\
\text { perhitungan secar } \\
\mathrm{KD}=\mathrm{R}^{2} \mathrm{X} 100 \%\end{array}$} & Model & $\mathrm{R}$ & R Square & $\begin{array}{l}\text { Adjusted R } \\
\text { Square }\end{array}$ & $\begin{array}{l}\text { Std. Error of the } \\
\text { Estimate }\end{array}$ & \\
\hline & 1 & $641^{\circ}$ &, 411 &, 375 & 214559901,489 & \\
\hline & a. Predi & (Constar & Biaya Maint & nce, Direct Labor & & \\
\hline
\end{tabular}

Dari tabel diatas dapat diketahui nilai $\mathrm{R}$ square adalah 0,411 , maka nilai tersebut mempunyai arti sebesar 41,1\% variasi dari variabel volume produksi dapat dipengaruhi oleh direct labor cost dan biaya maintanance mesin produksi injection. Sedangkan sisanya yaitu 0,589 atau $58,9 \%$ dari variabel volume produksi dipengaruhi variabel lainnya (faktor lain) yang tidak dimasukan.

\section{Uji Korelasi Pearson Product Moment}

Dimana didalam uji korelasi pearson product moment digunakan untuk mengetahui seberapa kuatkah hubungan diantara para variabel. Berikut adalah hasil pengolahan sebagai berikut: 
Tabel 4

Uji Korelasi Pearson Product Moment

Yang mana anali didapatkan angka pea volume produksi dan $\mathrm{s}$ Berdasarkan hasil uji

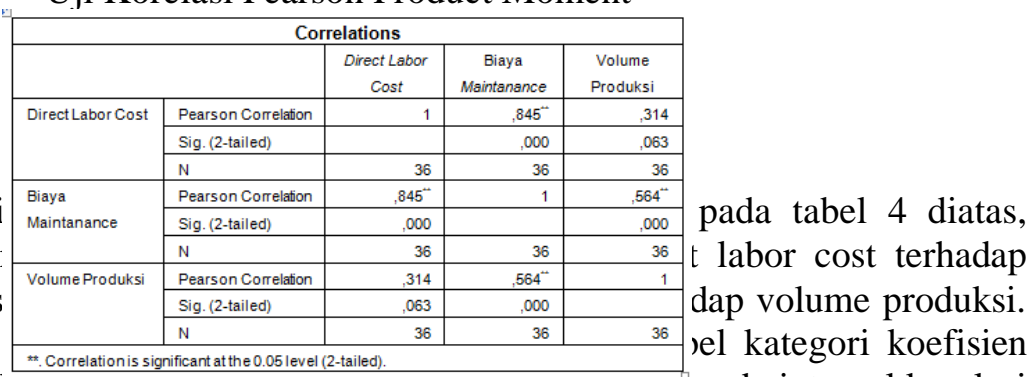
korelasi, bahwa direct labor cost ternadap volume produksi verada pada interval korelasi $(0,20-0,399)$ yang mana dapat ditarik kesimpulan memiliki tingkat hubungan yang rendah dan biaya maintanance terhadap volume produksi terdapapat pada interval korelasi $(0,40$ - 0,599) berada yang mana dapat ditarik kesimpulan memiliki tingkat hubungan yang sedang.

\section{Uji Korelasi Berganda}

Didalam uji korelasi berganda mempunyai kegunaan untuk mengetahui pengaruh secara bersama sama variabel. Berikut adalah hasil pengolahan sebagai berikut:

Tabel 5

\section{Uji Korelasi Berganda}

\begin{tabular}{|c|c|c|c|c|c|c|c|c|c|}
\hline \multicolumn{10}{|c|}{ Model Summary } \\
\hline & & & & Std. Error & & Char & e Statis & & \\
\hline Mode & $\mathrm{R}$ & $\begin{array}{c}\mathrm{R} \\
\text { Square }\end{array}$ & $\begin{array}{c}\text { Adjusted R } \\
\text { Square }\end{array}$ & $\begin{array}{c}\text { of the } \\
\text { Estimate }\end{array}$ & $\begin{array}{l}\text { R Square } \\
\text { Change }\end{array}$ & $\begin{array}{c}\mathrm{F} \\
\text { Change }\end{array}$ & df1 & $\mathrm{df} 2$ & $\begin{array}{c}\text { Sig. F } \\
\text { Change }\end{array}$ \\
\hline 1 &, $641^{\circ}$ &, 411 &, 375 & $\begin{array}{r}214559901 \\
489\end{array}$ & ,411 & 11,501 & 2 & 33 &, 000 \\
\hline
\end{tabular}

Y: a. Predictors: (Constant), Biaya Maintanance, Direct Labor Cost

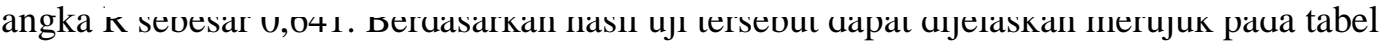
kategori koefisien korelasi yang mana masuk pada interval korelasi $(0,60-0,799)$ maka disimpulkan tingkat hubungan korelasi berganda atau secara simultan dari direct labor cost dan biaya maintanance mesin produksi injection terhadap volume produksi mempunyai tingkat hubungan yang kuat.

\section{Uji Hipotesis Statistik t (Parsial)}

Dimana didalam uji hipotesis statistik t menurut (Sugiyono, 2019) digunakan untuk melihat apakah terdapat pengaruh antar variabel secara sendiri-sendiri. Berikut adalah tabel hipotesis uji parsial yang diolah sebagai berikut:

Tabel 6

Uji Hipotesis Statistik t (Parsial)

\begin{tabular}{|c|c|c|c|c|c|c|}
\hline \multicolumn{7}{|c|}{ Coefficients $^{8}$} \\
\hline \multirow{2}{*}{\multicolumn{2}{|c|}{ Model }} & \multicolumn{2}{|c|}{ Unstandardized Coefficients } & \multirow{2}{*}{$\begin{array}{c}\text { Standardized } \\
\text { Coefficients } \\
\text { Beta }\end{array}$} & \multirow[t]{2}{*}{$t$} & \multirow[t]{2}{*}{ Sig. } \\
\hline & & $B$ & Std. Error & & & \\
\hline \multirow[t]{4}{*}{1} & (Constant) & 457899149,8 & 335248517,3 & & 1,366 &, 181 \\
\hline & & 71 & 82 & & & \\
\hline & DirectLabor Cost & $-4,847$ & 2,123 & .571 & $-2,283$ &, 029 \\
\hline & Biaya Maintanance & 54,526 & 13,036 & 1,047 & 4,183 &, 000 \\
\hline
\end{tabular}




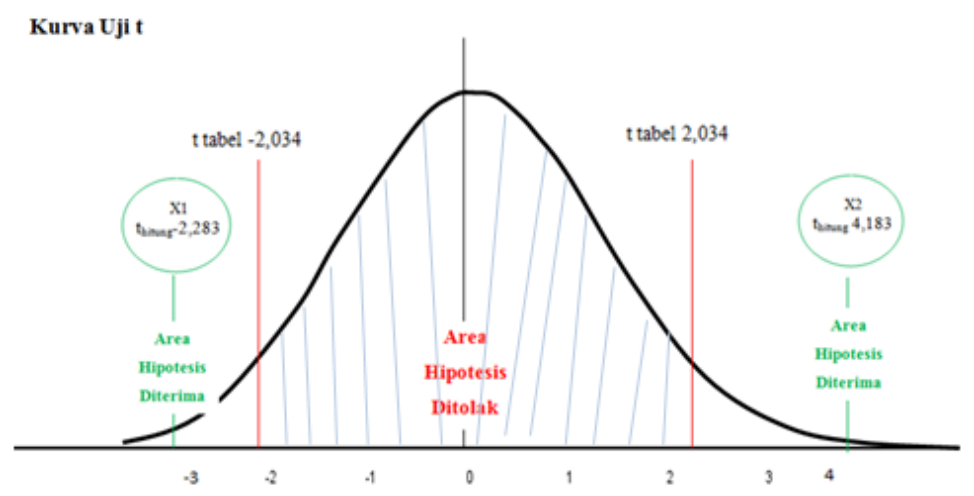

Gambar 1 Kurva Hasil Uji t (Parsial)

Yang mana hasil analisis uji $\mathrm{t}$ (parsial) ataupun sendiri sendiri yang dilihat tabel 6 diatas, yang didasari dari teori harga t hitung selanjutnya dibandingkan dengan $t$ tabel dan tingkat signifikansi $5 \%$ maka dapat dijelaskan sebagai berikut:

1. Melakukan hipotesis pengujian direct labor cost (X1) terhadap volume produksi (Y).

Berdasarkan hasil analisis pengujian direct labor cost terhadap volume produksi maka didapatkan angka sebesar $\mathrm{t}$ hitung $=(-2,283)$, yang mana terdapat tanda negatif yang terdapat di t hitung dianggap mutlak karena menggunakan uji 2 pihak, dengan dk atau derajat kebebasan sebesar 33 yang didapat dari $\mathrm{df}=\mathrm{n}-\mathrm{k}-1$ atau 36-2-1 dan jumlah $\mathrm{t}$ tabel sebesar 2,034. Maka analisis uji t tersebut dapat ditulis t hitung $(-2,283)<\mathrm{t}$ tabel $(-2,034)$, dikarenakan nilai -t hitung <-t tabel dan angka signifikansi senilai $0,029<0,05$ yang dapat disimpulkan bahwa Ha diterima dan Ho ditolak yang artinya terdapat pengaruh negatif antara direct labor cost terhadap volume produksi kursi plastik nappoly (big 909) studi kasus di PT. Cahaya Buana Intitama Bogor periode 2016-2018.

2. Melakukan hipotesis pengujian biaya maintanance mesin produksi injection (X2) terhadap volume produksi.

Berdasarkan hasil analisis pengujian biaya maintanance mesin produksi injection terhadap volume produksi maka didapatkan angka sebesar $\mathrm{t}$ hitung $=(4,183)$, karena menggunakan uji 2 pihak, dengan dk atau derajat kebebasan sebesar 33 yang didapat dari $\mathrm{df}=\mathrm{n}-\mathrm{k}-1$ atau 36-2-1 dan dalam $\mathrm{t}$ tabel sebesar 2,034. Maka analisis uji t tersebut dapat dituliskan $\mathrm{t}$ hitung $(4,183)>\mathrm{t}$ tabel $(2,034)$, dikarenakan nilai $\mathrm{t}$ hitung $>\mathrm{t}$ tabel maka angka signifikansi sebesar $0,000<0,05$ yang mana dapat disimpulkan bahwa Ha diterima dan Ho ditolak yang artinya terdapat pengaruh positif antara biaya maintanance mesin produksi injection terhadap volume produksi kursi plastik nappoly (big 909) studi kasus di PT. Cahaya Buana Intitama Bogor periode 2016-2018.

Yang mana analisis hipotesis statistik $\mathrm{f}$ (simultan) dapat dilihat pada tabel 1.6 diatas, yang didasari dari teori harga $f$ hitung selanjutnya dibandingkan dengan $f$ tabel dan tingkat signifikansi 5\% maka dapat dijelaskan sebagai berikut:

1. Melakukan pengujian hipotesis secara simultan yang berlandaskan nilai signifikansi

Hasil keluaran uji menghasilkan sig sebesar 0,000 yang mana didalam teori pengambilan keputusan $0,000<0,05$ maka disimpulkan bahwa berdasarkan taraf 
signifikansinya Ha diterima dan Ho ditolak yang artinya terdapat pengaruh secara simultan pengujian direct labor cost dan biaya maintanance mesin produksi injection terhadap volume produksi kursi plastik nappoly (big 909) study kasus di PT. Cahaya Buana Intitama.

\section{Melakukan pengujian hipotesis secara simultan berdasarkan $\mathrm{f}$ hitung dengan $\mathrm{f}$ tabel}

Dari hasil keluaran uji menghasilkan $\mathrm{f}$ shitung senilai sebesar 11,501 yang mana didalam teori keputusan $\mathrm{f}$ hitung 11,501 > f tabel 3,28 maka dapat ditarik kesimpulan berdasarkan nilai $\mathrm{f}$ hitung dan $\mathrm{f}$ tabel Ha diterima dan Ho ditolak yang artinya terdapat pengaruh secara bersama -sama pengujian direct labor cost dan biaya maintanace mesin produksi injection terhadap volume produksi kursi plastik nappoly (big 909) study kasus di PT. Cahaya Buana Intitama.

\section{Pembahasan}

Pengaruh Direct Labor Cost Terhadap Volume Produksi Kursi Plastik Nappoly (Big 909) Study Kasus Di PT. Cahaya Buana Intitama Bogor

Berikut pembahasan hasil penelitian Direct Labor Cost terhadap Volume Produksi menghasilkan hasil analisis uji t tersebut dapat dituliskan t hitung $(-2,283)<\operatorname{ttabel}(-2,034)$, dikarenakan nilai $-\mathrm{t}$ hitung $<-\mathrm{t}$ tabel dan angka sig senilai $0,029<0,05$ yang mana dapat disimpulkan Ha diterima dan Ho ditolak yang dijelaskan terdapat pengaruh negatif antara direct labor cost terhadap volume produksi kursi plastik nappoly (big 909) studi kasus di PT. Cahaya Buana Intitama Bogor periode 2016-2018. Berdasarkan hasil penelitian dapat diperkuat dengan penelitian terdahulu dan teori yaitu berdasarkan (Tukasno, 2017) bahwa penelitian tersebut variabel biaya tenaga kerja mempunyai pengaruh terhadap volume produksi pada volume produksi tungku didesa Braja Mulya Kecamatan Braja Selebah dan sejalan dengan teori (Sujarweni, 2015) menyatakan biaya tenaga kerja yang timbul dari pembuatan produksi yang langsung berhubungan dengan produk yang dihasilkan.

Pengaruh Biaya Maintanance Mesin Injection Terhadap Volume Produksi Kursi Plastik Nappoly (Big 909) Study Kasus Di PT. Cahaya Buana Intitama Bogor.

Berikut pembahasan hasil penelitian Biaya Maintanance Mesin Produksi Injection terhadap Volume Produksi menghasilkan analisis uji $\mathrm{t}$ tersebut dapat dituliskan $\mathrm{t}$ hitung $(4,183)>\mathrm{t}$ tabel $(2,034)$, dikarenakan nilai $\mathrm{t}$ hitung $>\mathrm{t}$ tabel dan angka sig senilai $0,000<$ 0,05 yang mana disimpulkan Ha diterima dan Ho ditolak yang artinya terdapat pengaruh positif antara biaya maintanance mesin produksi injection terhadap volume produksi kursi plastik nappoly (big 909) studi kasus di PT. Cahaya Buana Intitama Bogor periode 20162018. Berdasarkan hasil penelitian tersebut sejalan dan dapat diperkuat dengan teori menurut (Tampubolon, 2018) yang menyatakan bahwa kegiatan yang dilakukan untuk memelihara, memperbaiki, menjaga mesin dan peralatannya agar selalu berada dalam kondisi operasi yang siap pakai, sehingga kontinuitas proses produksi dapat berjalan sesuai dengan apa yang direncanakan dan keuntungan yang diharapkan dapat tercapai.

Pengaruh Direct Labor Cost dan Biaya Maintanance Mesin Produksi Injection Terhadap Volume Produksi Kursi Plastik Nappoly (Big 909) Study Kasus Di PT. Cahaya Buana Intitama Bogor.

Berikut pembahasan hasil penelitian Direct Labor Cost dan Biaya Maintanance Mesin Produksi Injection terhadap Volume Produksi menghasilkan analisis uji f secara simultan dapat dijelaskan berdasarkan nilai signifikansi nilai signifikansi sebesar 0,000 yang mana didalam teori pengambilan keputusan $0,000<0,05$ maka dari hasil tersebut dapat disimpulkan bahwa berdasarkan taraf signifikansinya Ha diterima dan Ho ditolak yang artinya terdapat pengaruh secara simultan pengujian direct labor cost dan biaya maintanance mesin produksi injection terhadap volume produksi kursi plastik nappoly (big 
909) study kasus di PT. Cahaya Buana Intitama dan berdasarkan nilai f hitung dengan $\mathrm{f}$ tabel, f hitung sebesar 11,501 yang mana didalam teori pengambilan keputusan $\mathrm{f}$ hitung 11,501 > 3,28 maka nilai tersebut dapat disimpulkan berdasarkan nilai f hitung dan $\mathrm{f}$ tabel Ha diterima dan Ho ditolak yang artinya terdapat pengaruh secara simultan pengujian direct labor cost dan biaya maintanance mesin produksi injection terhadap volume produksi kursi plastik nappoly (big 909) study kasus di PT. Cahaya Buana Intitama. Berdasarkan hasil penelitian ini sama dengan teori terdahulu yaitu sejalan dengan teori (Gitosudarmo, 2015) yang menyatakan volume produksi merupakan suatu interaksi antara bahan dasar, bahan pembantu, tenaga kerja, dan mesin-mesin serta alat pelengkapnya yang dipergunakan.

\section{KESIMPULAN}

Berdasarkan hasil analisis yang telah dilakukan oleh peneliti dalam melakukan pengujian yang terdapat di laporan skripsi dengn judul Pengaruh Direct Labor Cost dan Biaya Maintanance Mesin Produksi Injection terhadap Volume Produksi Kursi Plastik Nappoly (Big 909) study kasus di PT. Cahaya Buana Intitama Bogor disimpulkan antara lain:

1. Berdasarkan hasil pengujian yang dilakukan secara sendiri sendiri terdapat pengaruh negatif dalam Direct Labor Cost Terhadap Volume Produksi Kursi Plastik Nappoly (Big 909) Studi Kasus di PT. Cahaya Buana Intitama Bogor Periode 2016-2018.

2. Berdasarkan hasil pengujian yang dilakukan secara sendiri sendiri terdapat pengaruh secara positif dalam Biaya Maintanance Mesin Produksi Injection Terhadap Volume Produksi Kursi Plastik Nappoly (Big 909) Study Kasus di PT. Cahaya Buana Intitama Bogor periode 2016-2018.

3. Berdasarkan hasil pengujian yang telah dilakukan secara bersama sama terdapat pengaruh secara simultan dalam Direct Labor Cost dan Biaya Maintanance Mesin Produksi Injection Terhadap Volume Produksi Kursi Plastik Nappoly Big (909) Study Kasus di PT. Cahaya Buana Intitama Bogor.

\section{DAFTAR PUSTAKA}

Gitosudarmo, I. (2015) Manajemen Operasi. Edisi 3. Yogyakarta: BPFE UGM.

Herjanto, E. (2015) Manjemen Operasi. Edisi 3. Jakarta: Grasindo.

Mulyadi (2016). Akuntansi Biaya. Edisi Keli. Yogyakarta: UPP STIM YKPN.

Republik Indonesia. UU No 13 Tahun 2003. Sekretariat Negara. (2003). UU No 13

Tahun 2003.

Sugiyono (2019). Metode Penelitian Kuantitatif, Kualitatif, dan R \& D. Bandung: Alfabeta, CV.

Sujarweni, V. V. (2015). Akuntansi Biaya. Edisi 5. Yogyakarta: Pustaka Baru Press.

Sunyoto, D. (2016). Metodologi Penelitian Akuntansi. Bandung: PT. Refika Aditama. 